\title{
Relationship between Principal Change Management and Teacher Technology Integration in Schools
}

\author{
Wan Mohd Khairul Wan Isa, Mohamed Yusoff Mohd Nor, Jamalul Lail Abdul \\ Wahab
}

To Link this Article: http://dx.doi.org/10.6007/IJARBSS/v10-i11/7700

DOI:10.6007/IJARBSS/v10-i11/7700

Received: 27 September 2020, Revised: 25 October 2020, Accepted: 15 November 2020

Published Online: 27 November 2020

In-Text Citation: (Isa, Nor, \& Abdul Wahab, 2020)

To Cite this Article: Isa, W. M. K. W., Nor, M. Y. M., \& Abdul Wahab, J. L. (2020). Relationship between Principal Change Management and Teacher Technology Integration in Schools. International Journal of Academic Research in Business and Social Sciences. 10(11), 590-605

Copyright: (c) 2020 The Author(s)

Published by Human Resource Management Academic Research Society (www.hrmars.com)

This article is published under the Creative Commons Attribution (CC BY 4.0) license. Anyone may reproduce, distribute, translate and create derivative works of this article (for both commercial and non-commercial purposes), subject to full attribution to the original publication and authors. The full terms of this license may be seen

at: http://creativecommons.org/licences/by/4.0/legalcode

Vol. 10, No. 11, 2020, Pg. 590 - 605

Full Terms \& Conditions of access and use can be found at http://hrmars.com/index.php/pages/detail/publication-ethics 


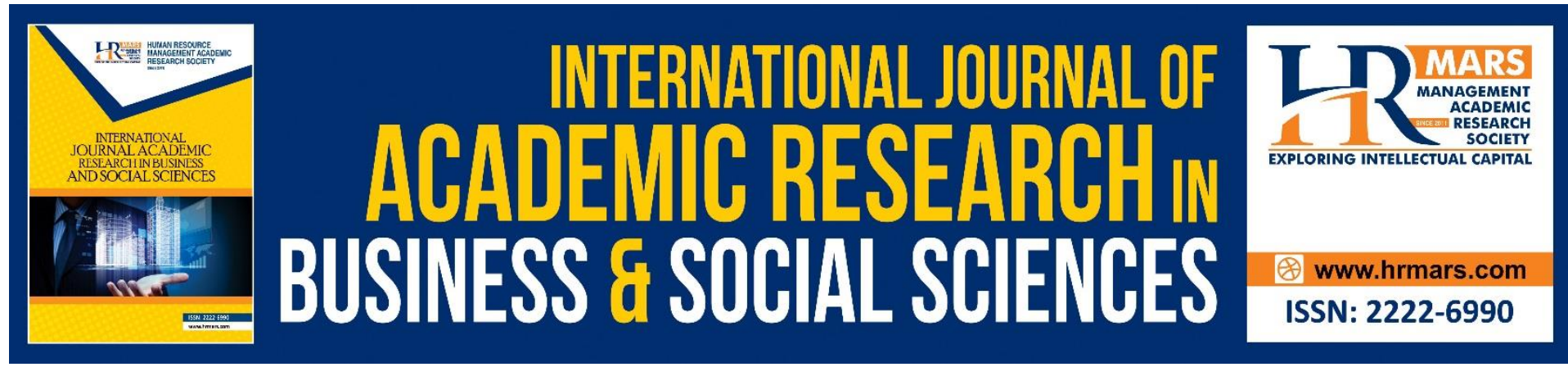

\title{
Relationship between Principal Change Management and Teacher Technology Integration in Schools
}

\author{
Wan Mohd Khairul Wan Isa, Mohamed Yusoff Mohd Nor, \\ Jamalul Lail Abdul Wahab \\ Faculty of Education, National University of Malaysia, Selangor, Malaysia
}

\begin{abstract}
This study examines the role of principals as facilitators of change in relation to the integration of technology in schools. For the purpose of this this study The Change Facilitator Style (CFS) model is used to identify leadership styles among school principals as change facilitators. On the other hand, Technology Integration Matrix (TIM) model is used to identify the level of technology integration within the features of a technology-integrated learning environment. This quantitative study is based on survey method to gather data from 580 participants. The instrument used for the study consisted of the dimensions of principals style as change facilitators based on three categories, namely Initiators, Managers, and Responders. Each category is assessed based on three sub-dimensions, namely the dimension of concern for people, organizational efficiency, and strategic sense. While the aspect of technology integration in the classroom is analysed based on the level of technology integration according to five stages of implementation, namely entry-level, adoption level, adaptation level, infusion level, and transformation level. In addition, the integration of technology was assessed based on the five characteristics of the learning environment, namely active learning, collaborative learning, constructive learning, authentic learning, and authentic learning. The findings show that the change facilitator style of different categories were evaluated between very low to high based on the different dimensions and categories. While the findings for the integration of technology were evaluated as high based all levels. The findings suggest that the principals have different styles in carrying out the role as change facilitator. The findings also suggest that there is a significant relationship between principal change management practices and the level of technology integration among teachers secondary schools of the central zone in peninsular Malaysia.
\end{abstract}

Keywords: Principal, Teacher, Change management, Technology integration, School.

\section{Introduction}

The challenge for school leaders today is to develop the ability to manage and lead change in the field of education. This is due to the rapid pace of digital environments that need to be fully utilized by teachers and students in schools. According to Fullan (2010), school leaders are individuals who are responsible as change managers and and it is their responsibility to lead the change in schools. As school-level managers, school leaders are the most important 
individuals who could influence the success of their school (Hallinger \& Lee, 2013). It is beyond doubt that the changes made are aimed at improving the education system at all levels and its success is closely related to organizational leadership capabilities (Ghitulescu, 2013).

The rapid change in the educational environment today not only requires school leaders to manage technology, but they also need to be involved in the process of exploring, evaluating, applying and operating various new technologies. At the same time they have to maintain a focus on teaching and learning as the main driving force (Creighton, 2011). New and acquired technology needs to go through a period of adaptation before reaching the maximum level of usage and thus creates an impact. Therefore, if schools are constantly upgrading technology regardless of the aspects and measures of its integration, the use of technology to increase teaching productivity could not be achieved.

\section{Research Background}

Over the past few decades, the element of leadership among school leaders has become a major topic frequently discussed in the field of education (Hall \& George, 1999; Hall \& Hord, 2014; Hougen, 1984; Schiller, 1991). The advent of the information and communication technology (ICT) era has further emphasized the importance of the role of school leaders in integrating innovations in the field of education into the classroom in their respective schools (Garland \& Tadeja, 2013). A review of the literature found that studies on the of the influence of change management on the integration of technology are still poor (Larosiliere, McHaney \& Kobelsky, 2016; Liu, Ritzhaupt \& Cavanaugh, 2013). Furthermore, the development of digital education today requires educational leaders to be vigilant towards the changes that occur in their environment. However, the failure of educational leaders who are not attentive towards the contemporary education needs leads to challenges in leading and managing change effectively (Burke, 2011; Burnes, 2014; Kotter, 2011; Kotter \& Rathgeber, 2014; Shariffah \& Kamaruzaman, 2013).

Past studies have found that the majority of organizational change initiatives as a whole, have failed (Beer \& Nohria, 2011; Burke, 2011; Judge \& Terrel, 2013; McKinsey \& Company, 2008). Although technology today has changed the operational mode of various sectors in the economy globally, the impact of technology on education sector, especially in relation to school change, however, is still unclear (Hess, 2009; Ministry of Education Malaysia, 2013; Larosiliere, McHaney \& Kobelsky, 2016). This is further strengthened by the findings of studies which suggest that technology is not fully utilized to change the implementation of teaching and learning activities because technology is considered as a mere tool to support existing practices (Bailey et al., 2011; Ehrlich, Sporte \& Sebring, 2013).

Based on literature review, it was also found that there is still a lack of research conducted focusing on developing framework on school leadership development in terms of technology management towards effective technology integration (Ahmad Zabidi, Abdul Rahman \& Nagarajan, 2015; Jainabee et al., 2011; Larosiliere, McHaney \& Kobelsky, 2016; Richardson et al., 2012). Although studies related to leadership, management, and technology in the field of education show an increase in the number of studies in some countries, however, the statistic is relatively low (Hallinger \& Chen, 2014; Liu, Ritzhaupt \& Cavanaugh, 2013). As such, the study of educational leadership and management practices of school leaders, especially in Malaysia, must be conducted continuously. It is an important process towards contributing more knowledge on various aspects of management that can be applied by school leaders. 


\section{Literature Review \\ Change Management}

In the context of education, change refers to the restructuring, development of schools or the basic needs of schools to implement any reform (Hallinger \& Lee, 2013). According to Jones (2007), change occurs as a result of actions for improvement, behavior or past circumstances and adapting it to current or new situations to further improve organizational efficiency. Hargreaves et al. (2011) explained that the implementation of change process is not meant for trying to overcome or eliminate all problems that exist in the organization but to make more innovative planning by taking into account the school situation in facing the pressure of change both internally and externally.

The main purpose of change is to adapt and align the organization with the current situation of the organizational environment that is constantly evolving and changing over time (Beerel, 2009). The ability of the organization to change according to the current situation creates more space and opportunities for the organization to make appropriate strategic reactions. The failure of the organization to change based on the situation or the failure to encourage change initiatives indicates the presence of weak organizational leadership. This certainly causes a detrimental effect on future survival of the organization. This is in line with the opinion of Beerel (2009) who explained that the two main reasons why an effort to create changes in the organization fails or is less effective are due to the failure to respond appropriately to the current situation and the fact that the organizational leaders do not play the right role to mobilize the organization in dealing with change.

Change management according to Brightman and Moran (2001) is a process of continuous improvement carried out by the organization in terms of direction, structure and ability to meet the ever-changing needs of customers. In this regard, change management is very important and necessary in an organization, either in terms of implementation aspect or the development of new organizational strategies (Burnes, 2014). In fact, successful organizations have shown the ability to effectively manage change as one of the most important forms of organizational competitiveness to maintain or improve organizational performance and success (Rigby \& Bilodeau, 2011).

Change management is a term that is commonly heard. However, with rapid and advanced technological change that is increasingly used or integrated in mobilizing the activities and journey of an organization, there is an increase in the need for the emergence of leaders to manage change (Rykrsmith, 2013).

\section{Technology Integration}

Technology-related innovations in the field of education refers to innovations that focus on improving the learning process and have created a competitive advantage in the field of education. In this regard, technology plays a role in enhancing the ability of teachers and their students in the learning process, improving the learning environment, encouraging the students' involvement and interaction in the learning environment, saving time and effort, and being able to follow the learning process anytime and anywhere (Alshehri, 2013). Furthermore, the current technology in education involves the application of the most current technology in multimedia. In relation to this, Nooriafshar (2012) found that the latest technological innovations in education focus on learning needs.

The integration of organizational technology includes the overall frequency and the pattern of technology usage, the development of teaching technology environments and the implementation of technology applications (Texas Education Agency, 2010). This includes 
classroom usage patterns, teaching environment design, use of technology to support subject objectives and use of technology applications. Accordingly, successful technology integration requires excellent technological infrastructure, quality professional training and development, and strong educational technology leadership (Crowther et al., 2002; Heifetz, 1994; Lim \& Khine, 2006).

The implementation of the technology integration process is influenced by various factors including leadership style, school size, staff background and interests, history of technology-related professional development initiatives as well as technology hardware and software resources (Phelps \& Graham, 2013). The rapid development in technology and the diversity of assumptions about how technology will transform the learning environment remains a major professional challenge faced by teachers. In fact, individuals who are using existing and up-to-date technology still need to face the prospect of the need to continue to learn and change, in line with future technological developments.

Therefore, the purpose of the study is to analyse the following:

- the level of change change management of principals in schools

- the level of teacher technology integration in schools

- the relationship between the level of principal change management and the level of teacher technology integration in schools

The discussion in this article will be based on the following research questions related to the management of principal changes and the integration of teacher technology as follows:

1. What is the level of change management of principals in schools?

2. What is the level of teacher technology integration in schools?

3. Is there a significant relationship between the level of principal change management and the level of teacher technology integration in schools?

In answering the third research question, the following hypotheses were also tested:

Ho1 There is no significant relationship between principal change management and teacher technology integration in schools.

\section{Research Methodology}

This quantitative study is based on a survey which involves data collection for the purpose of identifying the level of principal change management and technology integration in schools. In addition, it also seek to analyse the relationship between dependent variable and independent variable. According to Noraini (2013), a quantative study in the form of survey is conducted to obtain views from some of the population studied about an issue or problem, make observations on several variables of the study as well as to examine relationship between the variables. It is also used to identify trends in attitudes, behaviors, views and characters of a population (Creswell \& Plano Clark, 2018).

For the purpose of this study, the research population consisted of principals and teachers from Malaysian public secondary schools (SMK) in the central zone of Peninsular Malaysia, namely Selangor, the Federal Territory of Kuala Lumpur and the Federal Territory of Putrajaya. Overall, a total of 580 respondents consisting of principals and teachers who teach in public secondary shcools in the central zone of Peninsular Malaysia in the state of Selangor, Kuala Lumpur and Putrajaya were involved as research sample.

The research instrument looked at principal change management based on three dimensions of facilitator style in dealing with change i.e. concern for people, organizational 
efficiency and strategic sense. Next, data gathered based on the three dimensions of change facilitator style were used to classify the principals into three Change Facilitator Style (CFS) namely Initiators, Managers or Responders. The instruments used in this section had been translated and adapted from Change Facilitator Style Questionnaire (CFSQ) questionnaire by Hall and George (1999) and Hall and Hord (2014). Whereas, the instrument used to evaluate the technology integration during teaching and learning sessions in the classroom had been translated and adapted based on the Technology Integration Matrix (TIM) developed by Florida Center of Instructional Technology (FCIT), College of Education, University of South Florida (FCIT, 2019).

\section{Findings}

\section{The Level of Principal Change Management}

In this study, a scale of 1 to 6 was used to determine the level of change management of school principals according to the dimensions of change facilitator style. According to Leithwood, Jantzi and Steinbach (1999), the interpretation of levels for the scale of 1 to 6 is as follows:

a. Mean scores between 1.00 and 1.99 are categorized as very low levels;

b. Mean scores between 2.00 and 2.99 are categorized as low levels;

c. Mean scores between 3.00 and 3.99 were categorized as moderate levels;

d. Mean scores between 4.00 and 4.99 are categorized as high levels;

e. Mean scores between 5.00 to 6.00 are categorized as very high levels.

Accordingly, the analysis of the level of principal change management based on the dimensions of change facilitator style are shown in Table 1 below. The table shows the mean score (M) and standard deviation (SD) for each category of principal change facilitator style assessed based on the dimensions and subdimensions of the change facilitator style.

Table 1. Mean and standard deviation according to dimensions and subdimensions of Principal Change Facilitator style.

\begin{tabular}{lcccccc}
\hline Dimensions and Sub-dimensions & \multicolumn{3}{c}{ Principal Change Facilitator Style Profile } \\
\cline { 2 - 7 } Change Facilitator Style & \multicolumn{2}{c}{ Initiator } & \multicolumn{2}{c}{ Manager } & \multicolumn{2}{c}{ Responder } \\
& $M$ & $S D$ & $M$ & $S D$ & $M$ & $S D$ \\
Concern for People & & & & & & \\
$\quad$ i. Social / informal & 5.84 & 0.26 & 4.44 & 1.03 & 4.73 & 0.75 \\
$\quad$ ii. Formal / meaningful & 5.88 & 0.18 & 4.93 & 0.74 & 5.00 & 0.67 \\
Organizational Efficiency & & & & & & \\
$\quad$ i. Trust in others & 1.24 & 0.36 & 2.87 & 0.71 & 4.76 & 0.79 \\
$\quad$ ii. Administrative efficiency & 5.88 & 0.27 & 5.05 & 0.53 & 5.08 & 0.57 \\
Strategic Sense & & & & & & \\
$\quad$ i. Day-to-day & 1.24 & 0.33 & 2.73 & 0.60 & 4.60 & 0.81 \\
$\quad$ ii. Vision and planning & 5.92 & 0.18 & 5.06 & 0.61 & 5.12 & 0.62 \\
\hline
\end{tabular}

Table 1 shows the overall descriptive findings for each subdivision of Principal Change Facilitator style. These findings indicate that the principals in the Initiator change facilitator style category were evaluated by teacher respondents at a very high level of social/informal subdimension ( $M=5.84, S D=0.26$ ). These findings explain that principals in the Initiator style category implemented friendly and informal social interactions with teachers, prioritized teacher welfare in terms of emotions and had an open mind in accepting teachers' opinions. 
Meanwhile, social/informal subdimensions were evaluated at a high level for principals in the Manager style category $(M=4.44, S D=1.03)$ and Responder style category $(M=4.73, S D=$ 0.75). These analysis indicate that principals in the Manager style and Responder style category also carried out friendly and informal social interactions with teachers, but prioritized teachers' acceptance of themselves rather than teachers' welfare in terms of teachers' emotions and opinions.

Furthermore, the analysis in Table 1 also show that formal/meaningful subdimensions have been evaluated at a very high level for principals in the Initiator style category ( $M=5.88$, $S D=0.18)$ and Responder style category $(M=5.00, S D=0.67)$. These findings indicate that discussions and interactions between principals and teachers were more focused on teaching and learning in terms of ideas, activities and related issues. In fact, principals were also willing to provide support and guidance on the problems faced by teachers in performing their duties and responsibilities. While the principals in the Manager style category were evaluated at a high level for formal/meaningful subdimension $(M=4.93, S D=0.74)$. These findings explain that principals in the category of Manager style always provide support and guidance as well as discuss teachers' teaching and learning problems productively. In addition, principals also often focused on teachers' teaching and learning activities and also shared ideas in improving teaching and learning techniques for the purpose of school improvement.

In the subdimension of trust towards others, Table 1 shows that the mean score values are different for the three categories of change facilitator style. All items for the subdimension of trust towards others are negative in nature. Therefore, the mean score of low and very low value reflect a good and positive evaluation compared to the mean score of high and very high value. The analysis for the subdimension of trust in others indicates that principals in the category of Initiator style and Manager style were evaluated at very low levels ( $M=1.24$, SD $=0.36)$ and low $(M=2.87, S D=0.71)$ respectively. Meanwhile, the analysis of subdimension of trust in others for Responder style category was evaluated at a high level $(M=4.76, S D=$ 0.79). These analysis indicate that principals in the Initiator style and Manager style category perform resource management, task distribution and teacher work schedule as well as good and systematic time management procedures. On the other hand, principals in the Responder change facilitator style category have less effective and unsystematic resource management, task distribution, work procedures and time management.

Next, Table 1 explains that in terms of administrative efficiency subdimension, the mean score value for principals in all categories of change facilitator style is at a very high level for Initiator style category $(M=5.88, S D=0.27)$, Manager style category $(M=5.05, S D$ $=0.53)$ and Responder style category $(M=5.08, S D=0.57)$. These findings indicate that principals in all categories of change facilitator style have given priority in creating a clear work procedures, complete guidelines as well as efficient resource management in an effort to improve school effectiveness.

In the subdimension of daily activities, Table 1 shows that the mean score values are different for the three categories of change facilitator style. All items for the subdimension of daily activities are negative in nature. Therefore, the mean score of low and very low value shows good and positive evaluation or feature compared to the mean score of high and very high value. The analysis for the daily activity subdimension show that evaluation of principals in the Initiator style category and Manager style category are of very low levels ( $M=1.24, S D$ $=0.33)$ and low $(M=2.73, S D=0.60)$ respectively. Meanwhile, the daily activity subdimension for principals in the Responder style category was evaluated at a high level $(M=4.60, S D=$ 0.81 ). These findings indicate that principals in the category of Initiator style and Manager 
style implemented clear and good problem-solving measures, had good and clear ideas on improvement and innovations towards issues and needs of teachers and schools. On the other hand, principals in the Responder style category were seen to have limited innovation information and improvement ideas and provided less focus on main needs and issues in improving performance and achieve school goals.

Finally, Table 1 also shows that in terms of the sixth change facilitator style subdimension, namely vision and planning, the mean score value for principals in all change facilitator style categories is at a very high level for Initiator style category ( $M=5.92, S D=$ $0.18)$, followed by Manager style category $(M=5.06, S P=0.61)$ and Responder style ctageory $(M=5.12, S D=0.62)$. These findings indicate that principals in all categories of change facilitator style had a very broad knowledge and experience in the field of academic management and were able to master technological skills well. In addition, the principals were also actively involved in problem solving activities towards integrating long-term goals with the planning of daily school activities.

\section{The Level of Teacher Technology Integration}

The findings of the analysis of the level of teacher technology integration are shown in Table 2 below. The table shows the mean score (M) and standard deviation (SD) for each dimension of teacher technology integration.

Table 2. Mean and standard deviation of teacher technology integration level.

\begin{tabular}{llcc}
\hline Dimension & M & SD & $\begin{array}{c}\text { Level of } \\
\text { Interpretation }\end{array}$ \\
\hline Active Learning & 3.79 & .47 & High \\
Collaborative Learning & 3.75 & .51 & High \\
Constructive Learning & 3.89 & .51 & High \\
Authentic Learning & 3.86 & .45 & High \\
Goal-directed Learning & 3.84 & .54 & High \\
\hline Overall Technology Integration & 3.82 & .44 & High \\
\hline
\end{tabular}

Findings from Table 2 show that as overall, the level of technology integration of secondary teachers in the central zone of Peninsular Malaysia is at a high level for all dimensions of technology integration studied $(M=3.82, S D=0.44)$. These findings show that secondary school teachers in the central zone of Peninsular Malaysia are indeed practicing technology integration in schools. In detail, the findings also show that the practice of technology integration for the constructive learning dimension has become a priority with the highest mean score $(M=3.89, S D=0.51)$, followed by authentic learning dimension $(M=3.86$, $S D=0.45)$, learning in objective activities $(M=3.84, S D=0.54)$, active learning $(M=3.79, S D$ $=0.47)$, and finally the collaborative learning dimension $(M=3.75, S D=0.51)$.

Next, the findings of the analysis of the level of integration of teacher technology according to the category of principal change facilitator style are shown in Table 3 below. The table shows the mean score (M) and standard deviation (SD) for each principal change facilitator style profile which is assessed according to the dimensions of teacher technology integration. 
Table 3. Mean and standard deviation of teacher technology integration level according to the category of principal change facilitator style.

\begin{tabular}{|c|c|c|c|c|c|c|}
\hline \multirow[t]{3}{*}{ Dimension } & \multicolumn{6}{|c|}{ Principal Change Facilitator Style } \\
\hline & \multicolumn{2}{|c|}{ Initiator } & \multicolumn{2}{|c|}{ Manager } & \multicolumn{2}{|c|}{ Responder } \\
\hline & $M$ & $S P$ & $M$ & $S P$ & $M$ & $S P$ \\
\hline Active Learning & 4.67 & .58 & 3.94 & .67 & 3.77 & .44 \\
\hline Collaborative Learning & 4.54 & .51 & 4.01 & .54 & 3.72 & .50 \\
\hline Constructive Learning & 4.64 & .51 & 4.09 & .70 & 3.87 & .48 \\
\hline Authentic Learning & 4.66 & .56 & 4.01 & .70 & 3.84 & .42 \\
\hline Goal Directed Learning & 4.58 & .46 & 4.06 & .63 & 3.81 & .53 \\
\hline Overall Technology Integration & 4.63 & .51 & 4.01 & .62 & 3.80 & .42 \\
\hline
\end{tabular}

The Relationship Between Principal Change Management And The Integration Of Teacher Technology In Schools

For the purpose of this study, Pearson-r correlation analysis was undertaken to answer the third research question which is to determine the relationship between change management variables with the integration of technology in schools. Accordingly, this section will display the analysis of the relationship between principal change management through social/informal, formal/meaningful subdimensions, trust in others, administrative efficiency, daily activities as well as vision and planning with teacher technology integration. The results of correlation analysis in this study are determined by the value of the correlation coefficient ( $r$ ) based on the following interpretation (Davies, 1971):

a. The value of $r$ between 0.01 to 0.09 means that the relationship is negligible;

b. A value of $r$ between 0.10 to 0.29 means a low relationship;

c. The value of $r$ between 0.30 to 0.49 means a moderate relationship;

$d$. A value of $r$ between 0.50 to 0.69 means a strong relationship;

e. The value of $r$ between 0.70 to 0.99 means a very high relationship.

The results of Pearson-r correlation analysis are shown in Table 4 as follows.

Table 4. The relationship between change management and technology integration.

\begin{tabular}{llrr}
\hline & & \multicolumn{1}{c}{$\begin{array}{c}\text { Change } \\
\text { Management }\end{array}$} & $\begin{array}{c}\text { Technology } \\
\text { Integration }\end{array}$ \\
\hline Change Management & Pearson Correlation & 1 & $.199^{* *}$ \\
& Sig. (2-tailed) & 580 & .000 \\
& $\mathrm{~N}$ & $.199^{* *}$ & 580 \\
Technology Integration & Pearson Correlation & .000 & 1 \\
& Sig. (2-tailed) & 580 & 580 \\
\hline
\end{tabular}

**. Correlation is significant at the 0.01 level (2-tailed).

Based on Table 4, there is a significant positive relationship between principal change management practices with teacher technology integration with values of $r=0.199$ and sig $=$ 0.000 . The results of this analysis show that the strength of the relationship between principal change management and teacher technology integration is at a low level. Accordingly, the hypothesis that there is no significant relationship between principal change management 
and teacher technology integration is rejected. In other words, the practice of principal change management and the level of technology integration of teachers in secondary schools in central zone of Peninsular Malaysia has a significant relationship.

Table 5 further shows the results of Pearson-r correlation test between the dimensions of principal change management with teacher technology integration. The detailed analysis in Table 5 shows the relationship between each subdimension of facilitator change style for principal change management namely social/informal, formal/meaningful, trust in others, administrative efficiency, day-to-day activities as well as vision and planning with teacher technology integration based on Integration Matrix Technology (FCIT 2019).

Table 5. Pearson-r correlation values between the dimensions of change management with technology integration.

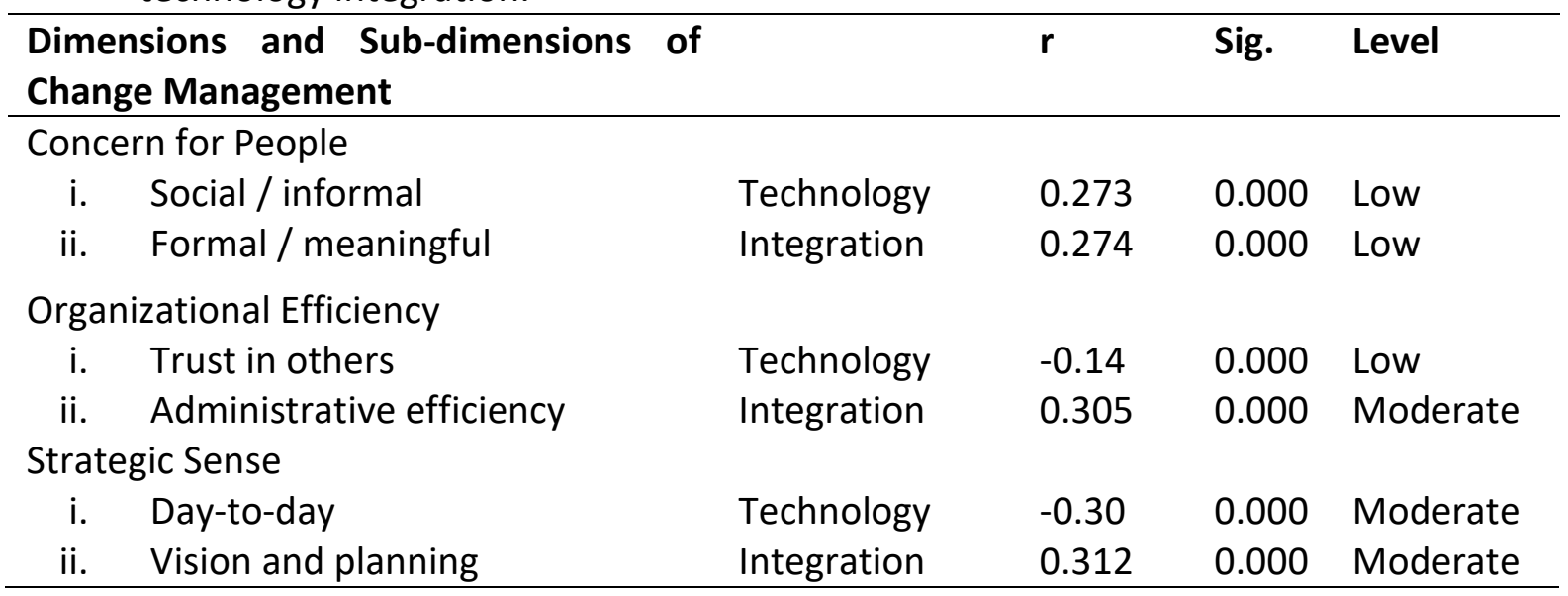

**. Correlation is significant at the 0.01 level (2-tailed).

Table 5 above shows that there is a significant relationship of low level between change management practices through social/informal subdimensions ( $r=0.273$, sig. $=0.000$, $p<0.05)$, formal/meaningful $(r=0.274$, sig. $=0.000, p<0.05)$ and trust in others $(r=-0.14$, sig. $=0.000, p<0.05$ ) with the level of integration of teacher technology in schools. While there is a significant relationship of moderate level between change management practices through the subdivision of administrative efficiency $(r=0.305$, sig. $=0.000, p<0.05)$, day-to day activities $(r=-.030$, sig. $=0.000, p<0.05)$ as well as vision and planning $(r=0.312$, sig. $=0.000$, $p<0.05$ ) with the level of integration of teacher technology in schools.

In conclusion, the analysis shows that there is a significant relationship of different levels between the principal change management through social / informal subdimensions (low level), formal/ meaningful (low level), trust in others (low level), administrative efficiency (moderate level), daily activities (medium level) as well as vision and planning (medium level) with the level of teacher technology integration in schools.

\section{Discussion}

\section{The Level of Principal Change Management Practice}

This section discusses the level of principal change management practices through the dimensions of change facilitator style i.e. concern for people, organizational efficiency and strategic sense. The findings of this study indicate that principals who adopt the Initiator change facilitator style have been evaluated at a high level in the four sub-dimensions of social/informal, formal/meaningful, administrative efficiency as well as vision and planning. Meanwhile, the other two sub-dimensions, namely trust in others and day-to-day planning, 
are evaluated at a low level. These findings explain that principals who adopt the Initiator style are more likely to have a clear and far-sighted vision and goals but at the same time still implement short-term change strategies. They are seen to have a clear view of the characteristics of the school as well as good instructional practices and subsequently work hard to build and achieve a vision towards it. Any decision made has to do with the goals of the school and it is guided by what he thinks is best for the students which refers to current practices for aspects of teaching and learning in the classroom.

The findings of this study also show that, principals who adopt the Manager style has been evaluated at a moderate level in all sub-dimensions of style facilitator change namely social/informal, formal/meaningful, trust in others, administrative efficiency, implementation of day-to-day activities as well as vision and planning. According to Hall and Hord (2014), these findings explain that principals in the Managers category show more consistent behavior in describing their responsive features to individuals or a given situation as well as initiating actions to support any change efforts. Such behavioral variations are seen to be related to their efforts to maintain good relationships with teachers and administrative staff so that a level of understanding and involvement in specific change efforts is obtained.

Furthermore, the findings of this study show that principals who adopt the Responder style has been evaluated at a high level in two sub-dimensions namely trust in others and the implementation of day-to-day activities. While the other four sub-dimensions are evaluated at a low level namely social/informal, formal/meaningful, administrative efficiency as well as vision and planning. These findings indicate that principals who are in the Responder category have a more open attitude by giving opportunities to senior assistants or middle leaders as well as teachers to lead the implementation of change. This is in line with what is suggested by Hall \& Hord (2014) who stated that the principal of the Responder category emphasizes the opportunity and freedom to lead an initiative among teachers and others compared to himself. They believe that their main task in the school is to ensure that the school runs smoothly by focusing on administrative matters, taking care of the needs of teachers and treating students well.

In conclusion, this study found that the level of change management practices of national secondary school principals (SMK) in the central zone of Peninsular Malaysia in the state of Selangor, the Federal Territory of Kuala Lumpur and the Federal Territory of Putrajaya as a whole are at a high level. Specifically, this study found that principals were more inclined to practice vision and planning, followed by administrative competence, formal/meaningful relationships, social/informal relationships, day to day activity planning and finally with trust in others.

\section{Level of Integration of Teacher Technology In Schools}

Technology in School Task Force (2002) defines the integration of technology as the integration of technology-related resources and technology-based practices into school routines, tasks and management. However, the success of the implementation of this technology integration is influenced by various factors. LoTi Connection (2016) in their study found that factors that influence the integration of technology by teachers in the classroom is the level of digital resource support readiness and shared digital learning vision.

The level of readiness for technology resource support and school vision sharing is identified to have a strong and positive relationship with the practice of using technology in the teaching of teachers in the classroom with correlation of 0.87 and 0.76 respectively (LoTi Connection, 2016). These two factors are seen to be closely related to the role of the principal 
as a technology leader in school, namely vision planner and systems designer (ISTE, 2018). Vision planner means that the principal involves the stakeholders to create a vision, strategic plan and continuous assessment system in changing the school environment as technologybased learning environment. While system designer means that principals form teams and systems to implement, maintain and continuously improve the level of the use of technology to support teaching and learning practices in schools.

Various parties have agreed on the importance of providing students with 21st century learning. Various definitions and frameworks related to the skills and teaching styles required for 21st century learning were also proposed by many such as Partnership for 21st Century Skills (2011), Saavedra and Opfer (2012), United States Department of Education (2014) and International Society of Technology in Education (2016). Critical thinking and problem solving skills, communication, collaboration as well as creativity and innovation are common features that are often mentioned in a series of discussions of 21st century learning features. These skills can be taught and learned most effectively by multiplying teaching and learning methods or pedagogy in an environment of effective technological integration (Brantley-Dias \& Ertmer, 2013; Saavedra \& Opfer, 2012).

Accordingly, this study looks at the integration of teacher technology in terms of the characteristics of the teaching and learning environment through the use of technology and at the same time maintain the main focus of implementation on students as proposed by the Florida Center for Instructional Technology or FCIT (2019) in Technology Integration Matrix (TIM). This study found that although the level of integration studied did not reach a very high level (mean $=4.21$ to 5.00 ), but the level of technology integration by the participants was still at a high level (mean $=3.41$ to 4.20 ) for all dimensions of technology integration involved. The findings show that the highest is the dimension of constructive learning, followed by authentic learning, goal-directed learning, active learning and finally collaborative learning.

Furthermore, the findings of this study also show that teachers serving in schools led by principals who adopt the Initiator change facilitator style assess themselves at the highest level for all dimensions of technology integration studied compared to teachers serving in schools led by a principal who adopts the Manager style and Responder style. These findings have indirectly shown that principals with Initiator change facilitator style profile have a high tendency to influence the level of technology integration in schools compared to the Change and Responder change facilitator style profile. However, it is undeniable that principals who adopt the style Manager and Responder also influence the implementation of good technology integration because the mean scores are still categorized as being high.

\section{The Relationship Between Principal Change Management and Teacher Technology Integration in Schools}

This study also identifies the relationship between principal change management practices and the level of technology integration by teachers in schools. In this study, the level of principal change management practices is seen through the dimensions of change facilitator style, namely concern for people, organizational efficiency and strategic sense. While the level of integration of teacher technology is seen through the dimensions of the characteristics of teaching and learning environment through the use of technology, namely active learning, collaborative learning, constructive learning, authentic learning and goal-directed learning. The analysis of the study show that there was a significant relationship between principal change management practices and the level of technology integration among teachers teaching in national secondary schools (SMK) in the central zone of Peninsular Malaysia in the 
state of Selangor, Federal Territory of Kuala Lumpur and Region Federation of Putrajaya. Accordingly, the null hypothesis suggesting that there is no significant relationship between the principal change management practices with teacher teechnology integration in schools has been successfully rejected. The results of the overall analysis on the level of relationship show a low level.

However, the analysis of detailed sub-dimensions in the principal change facilitator style with the integration of teacher technology suggest that not all dimensions in change facilitator style show the interpretation of low level. Out of the six subdimensions of change management facilitator style, only three subdimensions showed the interpretation of the relationships were at a low level namely social/informal, formal/meaningful and trust in others. While the remaining three subdimensions, namely administrative efficiency, day-today planning as well as vision and planning, show the interpretation of the relationship is at a moderate level.

\section{Conclusion}

The ability of an organization to implement change through a paradigm shift is a guarantee to achieve organizational excellence (Myers, Hulks \& Wiggins, 2012). Thus, the development aspect of school leaders to manage change, as well as the ability to integrate technology in schools, should be taken seriously in order to increase educational standards. This is in line with the aspirations of the country which to prepare the younger generation in facing the needs of the 21st century apart from increasing the expectations of parents and the community towards the national education policy (Ministery of Education Malaysia, 2013). Furthermore, studies on educational leadership and management practices on school leaders in Malaysia should be conducted continuously. It is an important process in providing more contribution to the body of knowledge on various aspects of management that can be applied by school leaders. Overall, this study examined the impact of change management on technology integration. Being able understand the aspects of technology integration from various perspectives developed from previous studies can help build a comprehensive perspective on the influence or the impact of change management on the technology integration process in schools.

The implications of this study are expected to contribute to the knowledge and understanding of the management and leadership practices of principals in influencing teachers to carry out teaching and learning tasks. In general, studies related to change management and technology management of leaders in the field of education in Malaysia are limited. Nevertheless, findings from this study indicate that there is a significant relationship between principal change management with the integration of teacher technology. Thus, the findings of this study directly support the Open System Theory (Hoy \& Miskel 2013) which explains that educational organizations such as schools are a system that has social relationships or interactions. Overall, the results of this study show that change management play an important role in influencing the success of technology integration in schools. Accordingly, the dimensions of change management such as organizational efficiency and change management strategies should be considered as important elements in planning programs involving technology integration in schools. 


\section{References}

Alshehri, A. M. (2013). Employing emerging technologies in educational settings: Issues and challenges. In Keengwe, J. (pnyt.). Research Perspectives and Best Practices in Educational Technology Integration. Hershey, Pennsylvania: Information Science Reference.

Bailey, A., Henry, T., McBride, L., \& Puckett, J. (2011). The Boston Consulting Group Report: Unleashing the Potential of Technology in Education, August 2011. http://imagesrc.bcg.com/Images/Unleashing_Potential_of_Technology_in_Education_tcm9111741.pdf [14 November 2017]

Beer, M., \& Nohria, N. (2011). Cracking the code of change. in. HBR's Must Reads on Change Management, (pp. 137-154). Massachusetts: Harvard Business School Publishing Corporation.

Beerel, A. (2009). Leadership and Change Management. Los Angeles: SAGE Publications.

Brantley-Dias, L., \& Ertmer, P. A. (2013). Goldilocks and TPACK: Is the construct "just right?". Journal of Research on Technology in Education 46(2), 103-128. doi:10.1080/15391523.2013.10 782615.

Brightman, B. K., \& Moran, J. W. (2001). Leading organizational change. Career Development International 6(2): 111-119.

Burke, W. W. (2011). Organization Change: Theory and Practice. 3rd Edition. California: SAGE Publications Inc.

Burnes, B. (2014). Managing Change. $6^{\text {th }}$ Ed. Harlow, England: Pearson Education Limited.

Creighton, T. (2011). Entrepreneurial leadership for technology: An opposable mind. in Papa, R. (pnyt.). Technology Leadership for School Improvement. California: SAGE Publications Inc.

Creswell, J. W., \& Clark, P. V. L. (2018). Designing and Conducting Mixed Methods Research. $3^{\text {rd }}$ Ed. Los Angeles: SAGE Publications Inc.

Crowther, F., Kaagan, S., Ferguson, M., \& Hann, L. (2002). Developing Teacher Leaders: How Teacher Leadership Enhances School Success. Thousand Oaks: Corwin Press.

Ehrlich, S. B., Sporte, S. E., \& Sebring, P. B. (2013). The Use of Technology in the Chicago Public Schools: Perspectives from Students, Teachers, and Principals. Chicago IL: the University of Chicago Consortium on Chicago School Research. https://consortium.uchicago.edu/sites/default/files/publications/Technology\%20Re port\%202013_0.pdf [05 Oktober 2018]

Florida Center for Instructional Technology (FCIT). (2019). The Technology Integration Matrix (TIM). University of South Florida. https://fcit.usf.edu/matrix/matrix/

Fullan, M. (2010). Leading Change. San Francisco: Jossey-Bass.

Garland, V. E., \& Tadeja, C. (2013). Educational Leadership and Technology: Preparing School Administrators for a Digital Age. New York: Routledge.

Ghitulescu, B. E. (2013). Making change happen: The impact of work context an adaptive and proactive behaviors. Journal of Applied Behavioral Science, 49(2), 206-245.

Hall, G. E., \& George, A. G. (1999). The impact of principal change facilitator style on school and classroom climate. in Jerome, F. H. (pnyt.). School Climate: Measuring, Improving and Sustaining Healthy, pp. 50-65. Philadelphia: Falmer Press.

Hall, G. E., \& Hord, S. M. (2014). Implementing Change: Patterns, Principles and Potholes. $4^{\text {th }}$ Ed. Upper Saddle River, New Jersey: Pearson. 
Hallinger, P., \& Chen, J. (2014). Review of research on educational leadership and management in Asia. Educational Management Administration \& Leadership 43(1): 527.

Hallinger, P., \& Lee, M. (2013). Exploring principal capacity to lead reform to teaching and learning quality in Thailand. Journal of Educational Development 33(4): 305-315.

Hargreaves, A., Lieberman, A., Fullan, M., \& Hopkins, D. (2011). Second International Handbook of Educational Change. New York: Springer.

Heifetz, R. A. (1994). Leadership Without Easy Answers. Cambridge: Belnap Press.

Hess, F. M. (2009). Private capital and private education: Toward quality a scale. The Future of American Education Working Paper Series 2009-02. American Enterprise Institute: Washington DC. http://mikemcmahon.info/EducationInvestment09.pdf

Hougen, M. C. (1984). High school principals: An analysis of their approach to facilitating implementation of microcomputers. PhD Thesis, University of Texas, Austin.

ISTE (International Society for Technology in Education). (2014). ISTE Essential Conditions Inventory Report On Validity and Reliability. Oregon: ISTE.

ISTE (International Society for Technology in Education). (2018). ISTE Standards for Educational Leaders. Oregon: ISTE.

Judge, W. Q., \& Terrel, R. S. (2013). Navigating the white water of organization-wide change: Best practice principles for change management. DIm. Carter, L., Sullivan, R. L, Goldsmith, M., Ulrich, D. \& Smallwood, N. (pnyt.). The Change Champion's Field Guide: Strategies and Tools for Leading Change in Your Organization. 2nd Edition. San Francisco: John Wileys \& Sons.

Jones, G. R. (2007). Organizational Theory, Design and Change. $5^{\text {th }}$ Ed. New Jersey: PearsonPrentice Hall.

Judge, W. Q., \& Terrel, R. S. (2013). Navigating the white water of organization-wide change: Best practice principles for change management. in Carter, L., Sullivan, R. L, Goldsmith, M., Ulrich, D. \& Smallwood, N. (pnyt.). The Change Champion's Field Guide: Strategies and Tools for Leading Change in Your Organization. 2nd Edition. San Francisco: John Wileys \& Sons.

Kotter, J. (2011). Leading change: Why transformation efforts fail. in. HBR's Must Reads on Change Management, pp. 1-16. Massachusetts: Harvard Business School Publishing Corporation.

Kotter, J., \& Rathgeber, H. (2014). Our Iceberg is Melting: Changing and Succeeding Under Any Conditions. London: McMillan.

Larosiliere, G. D., McHaney, R., \& Kobelsky, K. (2016). The effects of IT management on technology process integration. Journal of Computer Information Systems 56 (4): 341351. http://dx.doi.org/10.1080/08874417.2016.1164494 [24 Oktober 2017]

Lim, C. P., \& Khine, M. S. (2006). Managing teachers' barriers to ICT integration in Singapore schools. Journal of Technology \& Teacher Education 14(1): 97-125.

Liu, F., Ritzhaupt, A., \& Cavanaugh, C. (2013). Leaders of school technology innovation. Journal of Educational Administration 51(5): 576-593. http://dx.doi.org/10.1108/JEA-012012-0011

LoTi Connection. (2016). LoTi Digital Age Profile. 20 th Anniversary Edition. California: LoTi Connection. https://conference.iste.org/uploads/ISTE2016/HANDOUTS/ KEY_100410573/SampleGroupLoTiProfileReport20th.pdf [08 Feb 2019)]

McKinsey \& Company. (2008). McKinsey Global Survey Result: Creating organizational transformations. The McKinsey Quarterly July: 1-7. 
http://gsme.sharif.edu/ change/McKinsey\%20Global\%20Survey\%20Results.pdf [19 November 2018]

Ministry of Education. (2013). Malaysian Education Blueprint (Pelan Pembangunan Pendidikan Malaysia 2013-2025) Putrajaya: KPM.

Nooriafshar, M. (2012). Educational applications of the emerging technologies available on handheld divices such as iPad and iPhone. Asian Journal of Management Sciences and Education 1(1): 5-11.

Noraini, I. (2013). Reearch in Education (Penyelidikan dalam Pendidikan.) 2nd Ed.. McGrawHill Education.

Partnership for 21st Century Skills. (2011). Framework for 21st century learning. http://www.p21.org/storage/documents/1.__p21_framework_2-pager.pdf.

Phelps, R. \& Graham, A. (2013). Technology Together: Whole-School Professional Development for Capability and Confidence. Oregon: International Society for Technology in Education.

Richardson, J. W., Bathon, J., Flora, K. L., \& Lewis, W. D. (2012). NETS•A Scholarship: A Review of Published Literature. Journal of Research on Technology in Education 45(2): 131151.

Rigby, D., \& Bilodeau, B. (2011). Management Tools and Trends. Boston: Bain \& Company.

Rykrsmith, E. (2013). Change Management versus Change Leadership. https://www.quickbase.com/blog/change-management-versus-change-leadership [13 Februari 2018]

Saavedra, A. R., \& Opfer, V. D. (2012). Learning $21^{\text {st }}$ century skills requires $21^{\text {st }}$ century teaching. Phi Delta Kappan 94(2), 8-13. doi:10.1177/003172171209400203

Schiller, J. (1991). Implementing computer education: The role of the primary principal. Australian Journal of Educational Technology 7(1): 48-69.

Shariffah S. J. S. I., \& Kamaruzaman, M. (2013). The level of awareness, knowledge and leadership in managing change among educational leaders. (Tahap kesedaran, pengetahuan dan kepimpinan dalam mengurus perubahan dalam kalangan pemimpin pendidikan: perspektif pentadbir). Jurnal Pengurusan dan Kepimpinan Pendidikan 25(01): 77-90.

Technology in Schools Task Force. (2002). Technology in schools: Suggestions, tools and guidelines for assessing technology in elementary and secondary education. Washington, DC: US Department of Education, National Center for Educational Statistics

Texas Education Agency (TEA). (2010). The 2006 - 2010 Texas Campus STaR Chart. Instructional Materials and Educational Technology Division. http://starchart.esc12.net/ [12 Disember 2017]

United States Department of Education. (2014). Learning technology effectiveness. http://tech.ed.gov/learning-technol- ogy-effectiveness/

Zabidi A. R., Abdul Rahman, I., \& Nagarajan, K. (2015). Headmasters' competency in technology leadership (Kompetensi kepimpinan teknologi guru besar. Prosiding Seminar Nasional: Pengurusan dan Kepimpinan Pendidikan ke-21: 57-66. 